УДК 338.984.658.8

\title{
ФОРМУВАННЯ ТА ЗАПРОВАДЖЕННЯ НОВИХ КОМПОНЕНТІВ РОЗВИТКУ, ЩО ПІДВИЩУЮТЬ КОНКУРЕНТОСПРОМОЖНІСТЬ ПІДПРИЕМСТВА
}

( Н. О. Пархоменко, к.т.н., доцент, А. С. Проценко, магістрантка, Київський національний університет технологій та дизайну, Київ, Україна

В статье рассматриваются основные направления и новые компоненты повышения конкурентоспособности предприятий, которые зависят от их потенциальных возможностей, условий реализации стратегических направлений, развития и использования ресурсного обеспечения.

This paper examines the main trends and new components enhance the competitiveness of enterprises, depending on the capabilities, terms of strategic direction, development and utilization of resources.

\section{Постановка проблеми}

Актуальним на даному етапі розвитку економіки є завоювання Й утримання конкурентних переваг. Саме це $є$ ключовим фактором успіху підприємства в конкурентній боротьбі. Виробники постійно повинні відслідковувати зміну попиту, вартості сировинних ресурсів, вони повинні використовувати новітні підходи у сфері стратегічного маркетингу для підвищення рентабельності активів.

\section{Аналіз попередніх} досліджень

Проблемі конкурентоспроможності присвячено багато наукових робіт і книг [1-5], в яких закладено основи конкурентоспроможності та розкрито її суть i роль в розвитку суспільства. Але сучасні технології розвиваються так стрімко, що це поняття потребує постійного онов- лення і наповнення більш актуальним змістом.

\section{Мета роботи}

Метою роботи $є$ розкриття сучасних підходів до підвищення конкурентоспроможності підприемства на основі його потенційних можливостей.

\section{Результати проведених досліджень}

Як стверджував англійський економіст Ф. Хайєк, «суспільства, які покладаються на конкуренцію, успішніше за інших досягають своєї мети». Термін «конкуренція» походить від латинського слова concurrere, що означає «зіштовхуюсь». Конкурентоспроможність підприємства - здатність підприємства створювати, виробляти і продавати товари та послуги, цінові й нецінові якості яких привабливіші, ніж в ана- 
логічної продукції конкурентів.

Конкурентоспроможність фірми може бути визначена як їі порівняльна перевага відносно інших фірм цієї ж галузі усередині національної економіки і за ії межами. Це означає, що конкурентоспроможність фірми може бути виявлена (оцінена) лише в рамках групи фірм, які належать до однієї галузі, або фірм, що випускають товарисубститути. Конкурентоспроможність підприємства відіграє важливу роль для країни, адже підвищення конкурентоспроможності продукції на зовнішньому ринку дозволяе збільшити експорт, та врівноважити платіжний баланс [1, С. 384].

Як видно з табл. 1, в процесі оцінки конкурентоспроможності підприємства можуть використовуватися як кількісні, так і якісні показники.

Якісні показники використовуються в процесі оцінки у вигляді опису (образу) або у вигляді бальної оцінки якості, отриманої на основі експертного співставлення фактичного стану 3 найкращим.

Оцінка конкурентоспроможності підприємства може проводитися різними методами. Основними з них $€$ :

І. Метод різниць. Його суть полягає у визначенні переваг та недоліків підприємства за окремими показниками, що порівнюються (об'єктами оцінки). При застосуванні даного методу підприємство, що оцінюється, порівнюється тільки з одним підприємством-конкурентом [2, С. 120].

II. Метод рангів. Він визначає загальні положення, сильні та слабкі сторони підприємства, що оцінюється, в боротьбі з конкурентами.

Застосування даного методу ґрунтується на визначенні місця підприємств конкурентів за кожним об'єктом оцінки шляхом ранжування досягнених значень показників. Підсумовування місць (рангів) окремих підприємств за всіма показниками оцінки дозволяє виявити найбільш конкурентоспроможне підприємство за критерієм набраних рангів. Обраний принцип оцінювання повинен дотримуватися стосовно всіх показників оцінки.

Перевагою даного методу $€$ його простота, можливість застосування для оцінок як кількісних, так і якісних показників. В той же час даний метод дає тільки посередній результат, не дозволяє оцінити ступінь відставання підприємства від його основного конкурента [2, С. 121].

III. Метод балів. Його застосування дозволяє визначити узагальнюючу кількісну оцінку становища підприємства в конкурентній боротьбі при наявності кількох конкурентів.

Застосування даного методу передбачає: 1. Складання матриці оціночних показників для порівняння підприємства з його конкурентами.

2. Виділення найкращого значення окремого оціночного показника 3 даної сукупності підприємств та присвоєння йому визначеної бального значення (за самостійно встановленою шкалою оцінюванню).

3. Розрахунок балів, отриманих іншими підприємствами за даним оціночним показником 
Критерії та напрямки оцінки конкурентоспроможності

\begin{tabular}{|c|c|}
\hline Напрямки діяльності & Критерії та напрямки оцінки \\
\hline $\begin{array}{l}\text { 1. Торговельно-виробнича } \\
\text { діяльність }\end{array}$ & $\begin{array}{l}\text { Обсяг та склад товарообороту, послуг; виробнича } \\
\text { потужність торговельного підприємства; стан } \\
\text { торговельної мережі; обсяг, склад витрат обігу та } \\
\text { їх рівень; товарне забезпечення обороту; } \\
\text { організація торговельних процесів та } \\
\text { обслуговування споживачів, прогресивність } \\
\text { методів обслуговування, характер організації } \\
\text { торговельно-технологічних процесів }\end{array}$ \\
\hline 2. Фінансова діяльність & $\begin{array}{l}\text { Обсяг та структура капіталу, його ціна; } \\
\text { рентабельність діяльності та використання } \\
\text { капіталу; фінансове становище та } \\
\text { платоспроможність підприємства; обсяг та склад } \\
\text { оборотного капіталу та його використання; } \\
\text { тривалість операційного циклу та його окремих } \\
\text { елементів; структура та напрямки використання } \\
\text { фінансових ресурсів підприємства; рівень та } \\
\text { ритмічність виплати дивідендів; обсяг та склад } \\
\text { інвестиційних вкладень }\end{array}$ \\
\hline 3. Кадрова діяльність & $\begin{array}{l}\text { Забезпеченість робочою силою; продуктивність та } \\
\text { ефективність праці; рівень заробітної платні та } \\
\text { соціальних виплат, його відповідність ринковому } \\
\text { рівню; стабільність складу колективу та інше }\end{array}$ \\
\hline 4. Комерційна діяльність & $\begin{array}{l}\text { Асортиментна політика; цінова політика; рекламна } \\
\text { діяльність; організація господарських зв'язків, їх } \\
\text { стабільність та ефективність; характер } \\
\text { комерційних угод та їх ефективність; політика } \\
\text { формування торговельних надбавок; } \\
\text { конкурентоспроможність реалізованої продукції } \\
\text { (торгова марка, швидкість реалізації) та інше }\end{array}$ \\
\hline $\begin{array}{l}\text { 5. Організаційна та } \\
\text { управлінська діяльність }\end{array}$ & $\begin{array}{l}\text { Система планування; оперативне управління; } \\
\text { професійний рівень керівників та спеціалістів; } \\
\text { раціональність оргструктури; інформаційне } \\
\text { забезпечення, технологія управління та інше }\end{array}$ \\
\hline
\end{tabular}

шляхом порівняння їх фактичних значень найкращими в даній сукупності.

4. Встановлення значущості (вкладу) конкретного показника оцінки в загальну оцінку конкурентоспроможності підприємства.

Рівень значущості окремих оціночних показників задається експертно з урахуванням уявлення про роль даного показника в формуванні загального висновку про ступінь конкурентоспроможності підприємства.
5. Отримання узагальненої бальної оцінки конкурентоспроможності. Застосування цього методу дозволяє не тільки визначити основних конкурентів та місце в конкурентній боротьбі підприємства, яке оцінюється (за критерієм максимуму набраних балів), а й оцінити ступінь його наближення до найбільш конкурентоспроможного підприємства.

IV. Метод «еталону» (графічний метод). Цей метод використовується для наочного 
відображення зон конкурентних переваг та недоліків підприємства.

Для застосування методу необхідно:

1. Визначити напрямки (зони) оцінки конкурентоспроможності (5-6 зон).

2. Встановити максимальну (еталонну) кількість балів оцінювання, однакова за кожним напрямком.

3. Визначити кількість балів, набраних підприємством, що оцінюється, в порівнянні $з$ еталонним значенням.

4. Здійснити побудову графічної ілюстрації стану конкурентоспроможності підприємства.

Радіус еталонного кола та масштабування всього еталонного багатокутника визначається встановленим максимальним балом оцінювання. В управлінні конкурентоспроможністю підприємства виділяють такі фактори її підвищення:

1. За сферами впливу фактори поділяються на дві групи: внутрішні та зовнішні.

2. За змістом та способами впливу на конкурентоспроможність, виділяють також наступні фактори: ринкові, маркетингові, технологічні, фінансово-економічні, організаційноекономічні, соціальні тощо.

Оскільки головною причиною не конкурентоспроможності багатьох підприємств різних галузей $€$ недостатній науковотехнічний рівень промислових підприємств, то саме в цьому напрямку перш за все потрібно працювати.

Здійснення стратегії інноваційного розвитку можливе ли- ше через створення сприятливих умов для формування, використання та розвитку інтелектуального потенціалу як на рівні окремої людини, так і - підприємства, регіону, суспільства в цілому. Основою такої стратегії має бути створення правових, організаційних та економічних умов для підвищення рівня використання та розвитку інтелектуального та інноваційного потенціалу [4, C. 310].

Основні напрямки розвитку інтелектуального потенціалу та інноваційної діяльності для підвищення конкурентоспроможності: підвищення державного фінансування галузевої, вузівської та заводської науки; підтримання розвитку малих форм інвестиційної діяльності; створення сприятливих умов для вітчизняного та іноземного інвестування в пріоритетні наукоємні галузі; державні замовлення; пільгове кредитування; пільгова митна політика; цільове фінансування досліджень; державні гарантії щодо захисту авторських прав; сприяння створенню організацій для сприяння винахідництву, стимулювання інтелектуальної творчості на зразок міжкорпораційних кооперативних науково-технічних інститутів (США); стимулювання створення нової інноваційної інфраструктури: бізнес-інкубаторів, технополісів, технопарків; консорціумів промислових компаній, освітніх установ і наукових лабораторій; спеціалізованих інформаційно-консультативних центрів з питань науки і техніки, наукових парків та інноваційних центрів; доповнення 
форми стимулювання інноваційної діяльності такими заходами як безоплатні патентні послуги, звільнення від сплати мита, зниження державного мита для індивідуальних винаходів, створення фондів упровадження інновацій з урахуванням можливого ризику [5, С. 496].

Оскільки конкурентоспроможні товари - це результат функціонування конкурентоспроможного підприємства, то підвищення конкурентоздатності продукції теж є дуже важливим для підприємства.

Підвищення конкурентоспроможності продукції можна досягти наступними шляхами: зміною складу, асортименту, структурою застосовуваних матеріалів, що комплектують виріб або конструкції продукції; зміною порядку проектування продукції; технології виготовлення продукції, методів випробувань, системи контролю якості виготовлення, збереження, упакування, транспортування, монтажу; зміною цін на продукцію, цін на послуги, по обслуговуванню і ремонту, цін на запасні частини; порядку реалізації продукції на ринку; зміною структури і розміру інвестицій у розробку, виробництво і збут продукції; зміною структури й обсягів коопераційних постачань при виробництві продукції і цін на комплектуючі вироби і складу обраних поста- чальників; зміною системи стимулювання постачальників; зміною структури імпорту і видів імпортованої продукції [3, C. 23-24].

\section{Висновки}

Таким чином, високий динамізм розвитку зовнішнього середовища, зокрема споживчих вподобань, технологій, науки та техніки, інформаційного середовища переносить акценти управління конкурентоспроможності на здатність забезпечувати її і майбутньому. Єдиним механізмом, за рахунок якого це можливо здійснити - $є$ інформаційно-інноваційний. Якою б потужною не була інноваційна система підприємства, вона не буде значимим чинником конкурентоспроможності підприємства у майбутніх періодах без відповідного інформаційного забезпечення. Лише поєднання і єдиний неперервний цикл інформаційних потоків та інноваційних процесів дозволить підприємству впевнено почуватися у конкурентній боротьбі не лише у поточному періоді, а й у майбутньому.

Отже, для підвищення конкурентоспроможності, як продукції, так і підприємства загалом необхідно, перш за все, створити в державі сприятливі умови для ведення бізнесу та здійснювати інноваційну діяльність.

1. Должанський І. З. Конкурентоспроможність підприємства : Навчальний посібник / І. З. Должанський, Т. О. Загорна. - Київ : Центр навчальної літератури, 2006. - 384 с. 2. Заруба Ю. Б. Конкурентоспроможність підприємства / Ю. Б. Заруба // Фінанси України. - 2001. - № 2. С. 119-125. 3. Мазилкина Е. И. Основы управления конкурентоспособностью / Е. И. Мазилкина, Г. Г. Паничкина. - Саратов, 2005. - С. 23-24. 4. Сав- 
чук В. І. Системи управління конкурентоспроможністю / В. І. Савчук, Д. А. Корж. - К. : Знання, 2002. - 310 с. 5. Портер М. Конкуренция [Пер. з англ.] / М. Портер. - М. : ИД «Вильямс», 2000. - 496 с.

1. Dolzhanskyi I. Z. Konkurentospromozhnist pidpryiemstva : Navchalnyi posibnyk / I. Z. Dolzhanskyi, T. O. Zahorna. - Kyiv : Tsentr navchalnoi literatury, 2006. - 384 s. 2. Zaruba lu. B. Konkurentospromozhnist pidpryiemstva / lu. B. Zaruba // Finansy Ukrainy. - 2001. - № 2. - C. 119-125. 3. Mazilkina E. I. Osnovy upravlenija konkurentosposobnost'ju / E. I. Mazilkina, G. G. Panichkina. - Saratov, 2005. - S. 23-24. 4. Savchuk V. I. Systemy upravlinnia konkurentospromozhnistiu / V. I. Savchuk, D. A. Korzh. - K. : Znannia, 2002. 310 s. 5. Porter M. Konkurencija [Per. z anhl.] / M. Porter. - M. : ID «Vil'jams», 2000. $-496 \mathrm{~s}$

Рецензент - І. А. Ігнатьєва, д.е.н., професор, КНУТД

Надійшла до редакції 23.11.12 